

\section{Kalpataru}

Jurnal Sejarah dan Pembelajaran Sejarah

Volume 7, Nomor 1, Juli 2021

\section{Chief Editor}

Drs. Sukardi, M.Pd.

\section{Editor}

Dr. Muhamad Idris, M.Pd.

Eva Dina Chairunisa, M.Pd.

Jeki Sepriady, S.Pd.

\section{Reviewer}

Dr. Tahrun, M.Pd.

Drs. Supriyanto, M.Hum.

Dra. Retno Purwati, M.Hum.

Dr. Nor Huda Ali, M.Ag., M.A.

Dr. Budi Agung Sudarman, S.S., M.Pd.

Dr. Purmansyah, M.A.
(Universitas PGRI Palembang)

(Universitas Sriwijaya Palembang)

(Balai Arkeologi Sumatera Selatan)

(Masyarakat Sejarawan Indonesia Sumsel)

(Balai Bahasa Provinsi Sumatera Selatan)

(Universitas Muhammadiyah Palembang)

\footnotetext{
Alamat Redaksi

Program Studi Pendidikan Sejarah

Fakultas Keguruan dan IImu Pendidikan Universitas PGRI Palembang

Telp. 0711-510043

Email: jurnalkalpatarusejarah@gmail.com

Website: https://jurnal.univpgri-palembang.ac.id/index.php/Kalpa
} 


\section{Kalpataru}

JURNAL SEJARAH DAN

PEMBELAJARAN SEJARAH

Terbit dua kali setahun pada Juli dan Desember

Diterbitkan oleh:

Program Studi Pendidikan Sejarah Jurusan Pendidikan IPS

Fakultas Keguruan

dan IImu Pendidikan

Universitas PGRI Palembang

\section{DAFTAR ISI}

Nilai Budaya Masjid Jami' Sungai Lumpur Kelurahan II Ulu Palembang Sebagai Sumber Pembelajaran Sejarah

Maya Susanti, Muhamad Idris, Aan Suriadi.... $1-9$

Analisis Konsep Gender Dalam Undang-Undang Simbur Cahaya Sebagai Sumber Pembelajaran Sejarah Ruli Annisa, Muhamad Idris, Kabib Sholeh .... $10-18$

Perbedaan Model Pembelajaran Student Teams Achievement Divisions (STAD) dengan Model Pembelajaran Jigsaw Terhadap Hasil Belajar Siswa Pada Mata Pelajaran Sejarah di SMA Negeri 2 Mesuji Taufik Sidiki Al-Haq, Nur Ahyani, Ida Suryani.

Pengaruh Pemanfaatan Media Youtube Terhadap Hasil Belajar Siswa Mata Pelajaran Sejarah di SMK PGRI 2 Palembang

Riska Anggraini, Nur Ahyani, Ida Suryani. 28-36

Pengaruh Metode Pembelajaran Daring Terhadap Hasil Belajar Siswa Pada Mata Pelajaran Sejarah di Kelas XI IPA SMA Shailendra Palembang

Christina Leovita Saragih, Nur Ahyani, Aan Suriadi. $37-42$

Pengembangan Media Pembelajaran Digital Bukti-bukti Bangunan Masjid Kuno di Palembang Berbasis Android Varokah Widiyanti, Eva Dina Chairunisa, Ahmad Zamhari .

\section{Gambar Cover:}

Pohon Kalpataru

Candi Prambanan

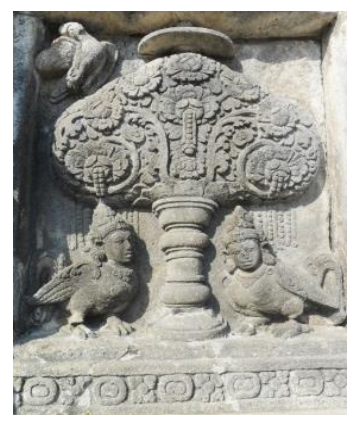

Koleksi: Muhamad Idris
Hubungan Jawa-Melayu Dalam Dunia Arsitektur Melayu Sumatera Selatan Reyvaldi Uyun, Muhamad Idris, Ahmad Zamhari.

Kondisi Politik Orde Baru di Gorontalo Tahun 19681998

Ferrari Yuliawati S, Suryo Ediyono. $61-67$

Nilai-nilai Sejarah dan Budaya Ikonografi Megalith di Lahat Sebagai Sumber Pembelajaran Sejarah Nasional Jainal Arifin, Sukardi, Dina Sri Nindiati.

Minat Siswa Terhadap Sejarah dan Budaya Palembang di SMA Negeri 15 Palembang Febbi Astuti, Muhamad Idris, Kabib Sholeh. $.77-82$ 


\title{
PENGARUH METODE PEMBELAJARAN DARING TERHADAP HASIL BELAJAR SISWA PADA MATA PELAJARAN SEJARAH DI KELAS XI IPA SMA SHAILENDRA PALEMBANG
}

\author{
Christina Leovita Saragih \\ Mahasiswa Program Studi Pendidikan Sejarah, FKIP Universitas PGRI Palembang \\ Email: kristinasaragih1608@gmail.com \\ Nur Ahyani \\ Dosen Program Studi Pendidikan Sejarah, FKIP Universitas PGRI Palembang \\ Email: nurahyani63@gmail.com \\ Aan Suriadi \\ Dosen Program Studi Pendidikan Sejarah, FKIP Universitas PGRI Palembang \\ Email: aandesalega30@yahoo.com
}

\begin{abstract}
ABSTRAK
Metode pembelajaran Daring adalah pembelajaran yang memanfaatkan teknologi multimedia, video, kelas virtual, teks online animasi, pesan suara, email, dan video streaming online. Pembelajaran dapat dilakukan secara masif dengan jumlah peserta yang tidak terbatas, bisa dilakukan secara gratis maupun berbayar. Masalah dalam penelitian ini adalah pengaruh metode pembelajaran Daring terhadap hasil belajar siswa pada mata pelajaran sejarah di kelas XI IPA SMA Shailendra Palembang. Metode penelitian yang digunakan adalah metode eksperimen. Berdasarkan hasil pembahasan didapat $t=11,6$ dari hasil tes yang dilakukan pada siswa eksperimen (menggunakan metode pembelajaran Daring) dapat diketahui bahwa rata-rata nilai siswa eksperimen adalah $x=75$, sedangkan nilai rata-rata untuk kelas kontrol (tidak menggunakan metode pembelajaran Daring) adalah $x=71$. Untuk hasil dari persentase koefisien kolerasi 9\%. Hasil yang diperoleh dari perhitungan uji-t korelasi didapat bahwa nilai $t=11,6$ sehingga $\mathrm{Ha}$ diterima dan Ho ditolak, dengan anggapan bahwa ada pengaruh metode pembelajaran Daring terhadap hasil belajar siswa pada mata pelajaran sejarah di kelas XI IPA SMA Shailendra Palembang.
\end{abstract}

Kata Kunci: Metode Pembelajaran Daring, Hasil Belajar Siswa.

\section{A. PENDAHULUAN}

Sistem pembelajaran modern berbasis teknologi informasi memberikan kualitas luasnya jangkauan yang sangat cocok untuk masyarakat milenial yang dapat diakses diberbagai tempat dan waktu. Sistem ini dapat diakses oleh berbagai level masyarakat dari menengah sampai sedang. Revolusi industri 4.0 memudahkan orang untuk terhubung secara online, seperti media sosial dan dapat mengakses informasi dengan cepat. Salah satu langkah pemanfaatan teknologi jaringan dan teknologi informasi bagi pengembangan sistem pembelajaran di sekolah adalah sistem Daring (dalam jaringan). Salah satu pemrakarsa dari sistem ini adalah Kementerian Pendidikan dan Kebudayaan Republik Indonesia. Kemendikbud melalui Direktorat Jenderal Pendidikan Tinggi membuat website pditt.belajar.kemdikbud.go.id yang diharapkan dapat menjadi sarana yang efektif bagi para pelajar dalam mempelajari ilmu tanpa batas. Proses belajar dengan cara ini dinilai sangat baik, karena sumber belajar dapat digunakan dengan gratis oleh ribuan orang yang membutuhkan (Mustofa, 2019:152).

Metode pembelajaran sangat dibutuhkan dalam sekolah, khususnya bagi pembelajaran di dalam kelas. Trianto (2010), menyebutkan bahwa model pembelajaran adalah suatu perencanaan atau pola yang digunakan sebagai pedoman dalam merencanakan pembelajaran di kelas atau pembelajaran tutorial. Pupuh dan Sobry S (2010) berpendapat makin tepat metode yang digunakan oleh guru dalam mengajar, diharapkan makin efektif pula pencapaian tujuan pembelajaran. 
Guru sejarah mengalami tantangan besar dalam proses pembelajaran secara Daring yang saat ini menjadi trend baru dalam dunia pendidikan Indonesia. Sejarah merupakan mata pelajaran yang menekankan aspek pendidikan nilai, bukan hanya menyampaikan informasi belaka. Hal ini menjadikan guru sejarah, secara mandiri harus mampu berinovasi, membuat skema pembelajaran yang mudah diterima oleh siswa di dalam sistem Daring. Faktanya, banyak sekali masalah atau problematika yang menghambat proses inovasi tersebut. Daring dianggap sebagai salah satu pemecahan masalah dikala Indonesia dan dunia sedang menghadapi pandemi Covid-19. Untuk tetap menjalankan kewajiban mendidik anak bangsa, kemajuan teknologi adalah sesuatu yang tidak bisa dihindari dalam kehidupan ini, karena kemajuan teknologi akan berjalan sesuai dengan kemajuan ilmu pengetahuan, maka semua ini pendidikan mulai beradaptasi dengan teknologi, mata pelajaran sejarah menjadi salah satu yang masuk di dalamnya.

Pembelajaran Daring merupakan pembelajaran yang memanfaatkan teknologi multimedia, video, kelas virtual, teks online animasi, pesan suara, email, dan video streaming online. Pembelajaran dapat dilakukan secara masif dengan jumlah peserta yang tidak terbatas, bisa dilakukan secara gratis maupun berbayar. Hal ini dilakukan untuk menghindari kontak langsung antara pendidik dan peserta didik yang mana sistem pembelajaran secara kovensional atau tatap muka dapat memperluas penyebaran virus Covid-19 (Jayul, 2020:190).

Metode pembelajaran Daring yang menjadi pilihan pertama, yaitu menggunakan fasilitas WA atau sering dikenal dengan WhatsApp, pemanfaatan WhatsApp digunakan guru sebagai sarana untuk mengumpulkan tugas. Penggunaan WhatsApp lebih praktis, lebih mudah dipahami anak, lebih efektif kerena tidak membutuhkan banyak kuota paket internet dalam proses pembelajaran. Kelebihan dalam penggunaan WhatsApp adalah lebih mudah dalam mengoperasikannya dan lebih mudah dalam pengiriman soal dan materi. Jikapun ingin melakukan pertemuan secara virtual maka guru dapat langung menggunakan fitur WhatsApp video call (Anugrahana, 2020:285).
Agar pembelajaran Daring dapat berjalan dengan baik, diperlukan persiapan oleh pihak sekolah, orang tua dan wali murid. Pihak sekolah memberikan fasilitas kepada guru berupa perangkat laptop atau handphone kepada guru dan paket internet yang diperlukan. Sedangkan pihak orang tua mempersiapkan perangkat handphone dan paket internet serta pendampingan terhadap putra putrinya. McKenna \& Strauser (2010) menyatakan persiapan pembelajaran Daring yang dapat dilakukan oleh guru SMA adalah mencari sumber daya web atau situs web yang menawarkan rencana dan kegiatan pembelajaran, kegiatan pembelajaran dilakukan menggunakan aplikasi, mengkomunikasikan kepada orang tua bahwa pembelajaran dilakukan secara Daring, tinjauan data penilaian untuk setiap anak, mengembangkan aspek perkembangan anak, guru memahami kurikulum dan materi pembelajaran yang akan dilaksanakan, meminta anak untuk melakukan rutinitas di rumah selama pembelajaran Daring, kagiatan pembelajaran dapat menggunakan alat dan bahan yang mudah dicari di sekitar rumah anak. Persiapan tersebut sangat penting dilakukan oleh guru agar pembelajaran Daring berjalan dengan efektif (Ayuni, 2021:415).

\section{B. METODE PENELITIAN}

Metode penelitian pada dasarnya adalah cara ilmiah untuk mendapatkan data dengan tujuan dan kegunaan tertentu. Namun peneliti mengambil metode kuantitatif. Metode kuantitatif dinamakan metode tradisional, karena metode ini sudah cukup lama digunakan sehingga sudah mentradisi sebagai metode untuk penelitian (Sugiyono, 2011:7-8).

Dalam metode penelitian ini penulis menggunakan metode kuantitatif menurut Sugiyono (2019:15). Metode kuantitatif adalah metode yang penelitiannya berupa angka-angka dan analisis mengggunakan statistik. Teknik pengambilan sampel pada umumnya dilakukan secara random, pengumpulan data menggunakan instrumen penelitian analisis data bersifat kuantitatif statistik dengan tujuan untuk menguji hipotesis yang ada.

Dalam penelitian ini peneliti menggunakan metode eksperimen. Dengan 
cara menentukan kelas eksperimen dan kelas kontrol. Pengajaran sesuai dengan kelasnya, kelas eksperimen menggunakan metode pembelajaran Daring sedangkan kelas kontrol tidak menggunakan model pembelajaran Daring kemudian memberi tes soal yang sama. Metode eksperimen ini dilakukan untuk memperoleh gambaran bagaimana hasil belajar siswa dalam mata pelajaran sejarah. Penelitian ini memperoleh data hasil belajar secara menyeluruh dengan menggunakan metodemetode pembelajaran Daring yang dapat meningkatkan semangat siswa dalam memperoleh pembelajaran dari guru walaupun pembelajaran dilakukan secara Daring (dalam jaringan).

\section{HASIL DAN PEMBAHASAN}

Penelitian ini merupakan penelitian dengan bentuk Quasi Eksperimen Design. Penelitian tersebut menyelidiki kemungkinan mengenai sebab dan akibat di mana dalam penelitian secara nyata ada kelompok perlakuan dan ada kelompok kontrol. Kelompok eksperimen dan kelompok kontrol dipilih 2 kelas dari seluruh jumlah populasi, yakni kelas XI IPA 1 untuk kelompok kontrol yang mendapat pembelajaran dengan menggunakan metode pembelajaran konvensional. Kelas XI IPA 2 untuk kelompok eksperimen yang mendapat pembelajaran dengan menggunakan metode pembelajaran Daring.

Peneliti menggunakan hasil nilai mata pelajaran sejarah yang telah dilakukan oleh guru di semester genap tahun ajaran 2020/2021. Berikut ini nilai mata pelajaran sejarah siswa di semester genap tahun ajaran 2020/2021.

Tabel 1

Daftar Nilai Awal (Pretest) Kelas XI IPA 1 (Kontrol) dan XI IPA 2 (Eksperimen)

\begin{tabular}{|c|l|c|c|l|c|}
\hline \multirow{2}{*}{ No } & \multicolumn{2}{|c|}{ Kelas Kontrol } & \multirow{2}{*}{ No } & \multicolumn{2}{c|}{ Kelas Eksperimen } \\
\cline { 2 - 3 } \cline { 5 - 6 } & Nama Siswa & Nilai & Nama Siswa & Nilai \\
\hline 1 & $\begin{array}{l}\text { Amanda } \\
\text { Putri } \\
\text { Oktarina }\end{array}$ & 76 & 1 & $\begin{array}{l}\text { Amelia Putri } \\
\text { Hardiyanti }\end{array}$ & 76 \\
\hline 2 & $\begin{array}{l}\text { Amelia } \\
\text { Kristina }\end{array}$ & 66 & 2 & $\begin{array}{l}\text { Ayu Ameliza } \\
\text { Malay }\end{array}$ & 70 \\
\hline 3 & $\begin{array}{l}\text { Anisah Dwi } \\
\text { Anggraini }\end{array}$ & 63 & 3 & Aurel Kriswara & 69 \\
\hline 4 & Charissa & 66 & 4 & Bella Puspita & 70 \\
\hline
\end{tabular}

\begin{tabular}{|c|l|c|c|l|c|}
\hline \multirow{2}{*}{ No } & \multicolumn{2}{|c|}{ Kelas Kontrol } & \multirow{2}{*}{ No } & \multicolumn{2}{c|}{ Kelas Eksperimen } \\
\cline { 2 - 3 } \cline { 5 - 6 } & Nama Siswa & Nilai & & Nama Siswa & Nilai \\
\hline 5 & $\begin{array}{l}\text { Cindy Erinda } \\
\text { Putri }\end{array}$ & 56 & 5 & Cika Rani & 73 \\
\hline 6 & Dwi Audina & 53 & 6 & Dini Anggraini & 83 \\
\hline 7 & $\begin{array}{l}\text { Langgeng } \\
\text { Ramadhani }\end{array}$ & 66 & 7 & Dova Marseli & 73 \\
\hline 8 & Lyra Amelia & 86 & 8 & Dwi Novriyanto & 83 \\
\hline 9 & M. Arief & 83 & 9 & Elenika & 80 \\
\hline 10 & $\begin{array}{l}\text { M. Ridho } \\
\text { Firmansyah }\end{array}$ & 83 & 10 & Fadilla & 70 \\
\hline 11 & $\begin{array}{l}\text { Maulina } \\
\text { Septiana }\end{array}$ & 80 & 11 & Fahrul Rozi & 80 \\
\hline 12 & $\begin{array}{l}\text { May Nadya } \\
\text { Putri N. }\end{array}$ & 80 & 12 & $\begin{array}{l}\text { lqbal Muqtadir } \\
\text { Albar }\end{array}$ & 83 \\
\hline
\end{tabular}

Tabel 2

\section{Nilai Posttest Mata Pelajaran IPS Kelas} Eksperimen dan Kelas Kontrol

\begin{tabular}{|c|c|c|c|c|c|}
\hline \multirow[b]{2}{*}{ No } & \multicolumn{2}{|c|}{ Kelas Kontrol } & \multirow[b]{2}{*}{ No } & \multicolumn{2}{|c|}{ Kelas Eksperimen } \\
\hline & $\begin{array}{l}\text { Nama } \\
\text { Siswa }\end{array}$ & $\begin{array}{l}\text { Nilai } \\
\text { Akhir }\end{array}$ & & $\begin{array}{l}\text { Nama } \\
\text { Siswa }\end{array}$ & $\begin{array}{l}\text { Nilai } \\
\text { Akhir }\end{array}$ \\
\hline 1 & $\begin{array}{l}\text { Amanda } \\
\text { Putri } \\
\text { Oktarina }\end{array}$ & 76 & 1 & $\begin{array}{l}\text { Amelia } \\
\text { Putri } \\
\text { Hardiyanti }\end{array}$ & 76 \\
\hline 2 & $\begin{array}{l}\text { Amelia } \\
\text { Kristina }\end{array}$ & 66 & 2 & $\begin{array}{l}\text { Ayu } \\
\text { Ameliza } \\
\text { Malay }\end{array}$ & 70 \\
\hline 3 & $\begin{array}{l}\text { Anisah Dwi } \\
\text { Anggraini }\end{array}$ & 63 & 3 & $\begin{array}{l}\text { Aurel } \\
\text { Kriswara }\end{array}$ & 69 \\
\hline 4 & Charissa & 66 & 4 & $\begin{array}{l}\text { Bella } \\
\text { Puspita }\end{array}$ & 70 \\
\hline 5 & $\begin{array}{l}\text { Cindy } \\
\text { Erinda Putri }\end{array}$ & 56 & 5 & Cika Rani & 73 \\
\hline 6 & Dwi Audina & 53 & 6 & $\begin{array}{l}\text { Dini } \\
\text { Anggraini }\end{array}$ & 83 \\
\hline 7 & $\begin{array}{l}\text { Langgeng } \\
\text { Ramadhani }\end{array}$ & 66 & 7 & $\begin{array}{l}\text { Dova } \\
\text { Marseli }\end{array}$ & 73 \\
\hline 8 & Lyra Amelia & 86 & 8 & $\begin{array}{l}\text { Dwi } \\
\text { Novriyanto }\end{array}$ & 83 \\
\hline 9 & M. Arief & 83 & 9 & Elenika & 80 \\
\hline 10 & $\begin{array}{l}\text { M. Ridho } \\
\text { Firmansyah }\end{array}$ & 83 & 10 & Fadilla & 70 \\
\hline 11 & $\begin{array}{l}\text { Maulina } \\
\text { Septiana }\end{array}$ & 80 & 11 & Fahrul Rozi & 80 \\
\hline 12 & $\begin{array}{l}\text { May Nadya } \\
\text { Putri N. }\end{array}$ & 80 & 12 & $\begin{array}{l}\text { Iqbal } \\
\text { Muqtadir } \\
\text { Albar }\end{array}$ & 83 \\
\hline & Jumlah & 855 & & Jumlah & 907 \\
\hline & Rata-rata & 71 & & Rata-rata & 75 \\
\hline & lai Tertinggi & 86 & & ai Tertinggi & 83 \\
\hline & ai Terendah & 53 & & ai Terendah & 69 \\
\hline
\end{tabular}

(Sumber: Tata Usaha SMA Shailendra

Palembang) 
Gambar 1

Diagram Batang Nilai Posttest Kelas Kontrol dan Kelas Uji

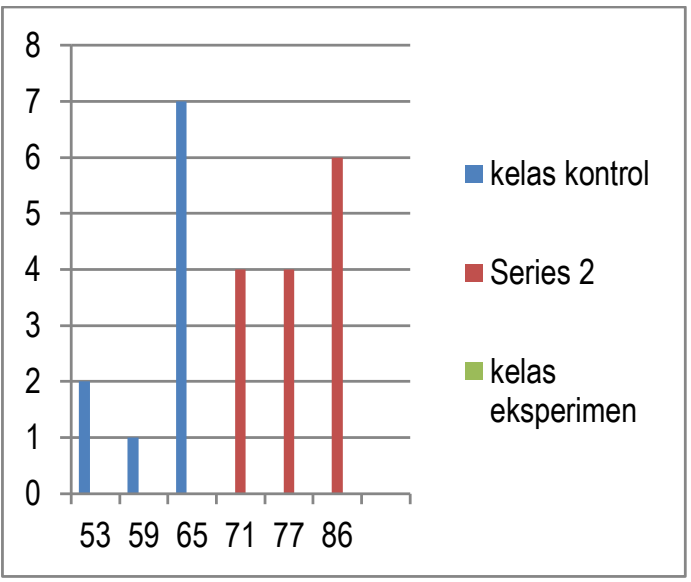

Dari diagram batang pada gambar $1 \mathrm{di}$ atas menunjukkan bahwa hasil belajar sejarah kelas XI IPA 2 (kelas uji) lebih rendah nilainya dibandingkan dengan hasil belajar sejarah kelas XI IPA 1 (kelas kontrol). Setelah data tersebut diperoleh maka selanjutnya akan dilakukan analisis terhadap hasil penelitian tersebut. Analisis data penelitian meliputi uji validitas, uji reabilitas, uji normalitas, uji homogenitas, uji hipotesis yang digunakan untuk mengetahui pengaruh dari metode pembelajaran Daring terhadap hasil belajar siswa pada mata pelajaran sejarah kelas XI IPA di SMA Shailendra Palembang.

Data yang diperoleh dari hasil nilai tes tentang materi Strategi Mempertahankan Kemerdekaan Indonesia pada kelas XI IPA 2 (sebagai kelas uji) dengan diterapkannya metode pembelajaran Daring dan kelas XI IPA 1 (sebagai kelas kontrol) dengan tidak diterapkannya metode pembelajaran Daring. Soal yang diberikan pada kedua kelas yakni 30 soal pilihan ganda.

Dari diagram batang pada gambar $1 \mathrm{di}$ atas menunjukkan bahwa hasil belajar sejarah kelas XI IPA 2 (kelas uji) lebih rendah nilainya dibandingkan dengan hasil belajar sejarah kelas XI IPA 1 (kelas kontrol). Setelah data tersebut diperoleh maka selanjutnya akan dilakukan analisis terhadap hasil penelitian tersebut. Analisis data penelitian meliputi uji validitas, uji reabilitas, uji normalitas, uji homogenitas, uji hipotesis yang digunakan untuk mengetahui pengaruh dari metode pembelajaran Daring terhadap hasil belajar siswa pada mata pelajaran sejarah kelas XI IPA di SMA Shailendra Palembang.

Tabel 3

\section{Deskripsi Analisis Hasil Tes Soal Siswa Kelas Eksperimen}

\begin{tabular}{|c|c|c|c|c|}
\hline Kelas & $\begin{array}{c}\text { Rata- } \\
\text { Rata }\end{array}$ & $\begin{array}{c}\text { Nilai } \\
\text { Maksimal }\end{array}$ & $\begin{array}{c}\text { Nilai } \\
\text { Minimal }\end{array}$ & Rentang \\
\hline Eksperimen & 75 & 83 & 69 & 14 \\
\hline
\end{tabular}

(Sumber: data Output SPSS 20 for windows)

Berdasarkan data pada tabel di atas dapat disimpulkan nilai rata-rata kelas eksperimen (XI IPA 2) adalah 75 dengan nilai maksimal yakni 86 dan nilai minimal yakni 53 . Sedangkan rentang yakni 14 diperoleh dari hasil nilai tertinggi dikurang nilai terendah di kelas eksperimen.

Tabel 4

\section{Deskripsi Analisis Hasil Tes Soal Siswa Kelas Kontrol}

\begin{tabular}{|c|c|c|c|c|}
\hline Kelas & $\begin{array}{c}\text { Rata- } \\
\text { Rata }\end{array}$ & $\begin{array}{c}\text { Nilai } \\
\text { Maksimal }\end{array}$ & $\begin{array}{c}\text { Nilai } \\
\text { Minimal }\end{array}$ & Rentang \\
\hline Kontrol & 71 & 86 & 53 & 33 \\
\hline
\end{tabular}

(Sumber: data Output SPSS 20 for windows)

Berdasarkan data pada tabel di atas dapat disimpulkan nilai rata-rata kelas kontrol (XI IPA 1) adalah 71 dengan nilai maksimal yakni 86 dan nilai minimal 53. Sedangkan rentang yakni 33 diperoleh dari hasil nilai tertinggi dikurangi nilai terendah di kelas kontrol.

\section{Uji Normalitas Data}

Uji normalitas yang dilakukan dalam penelitian ini dilakukan dengan menggunakan uji Chi Kuadrat, yang dimana jika $X^{2}{ }_{\text {hitung }} \geq X^{2}$ tabel, maka distribusi data Tidak Normal dan jika $X^{2}$ hitung $\leq X^{2}$ tabel, makadistribusi data Normal.

\section{Pengujian Homogenitas}

Dalam penelitian ini, homogenitas data di uji dengan menggunakan SPSS 20.0 yakni dengan Levene Statistic, yang mana data dikatakan homogen apabila nilai Signifikan > 0.05 maka data varians diterima dan jika nilai 
Signifikan $<0,05$ maka data varians ditolak atau tidak homogen.

\section{Test of Homogeneity of Variances}

Tingkat Pengetahuan

\begin{tabular}{|r|r|r|r|}
\hline Levene Statistic & \multicolumn{1}{c|}{ df1 } & \multicolumn{1}{c|}{ df2 } & Sig. \\
\hline .515 & 1 & 58 & .476 \\
\hline
\end{tabular}

(Sumber: data Output SPSS 20.0 for windows)

Berdasarkan uji homogenitas pada tabel di atas, maka dapat kita lihat bahwa nilai signifikasi hasil sebesar 0,476 dengan $a=0,05$ karena 0,476 lebih besar dari Signifikan maka data tersebut bersifat homogen $(0,476>0,05)$. Jadi dapat disimpulkan bahwa hasil tes akhir hasil belajar mata pelajaran sejarah dalam penelitian ini bersifat homogen.

\section{Pengujian Hipotesis}

Dalam penelitian ini peneliti menggunakan t-test untuk menguji hipotesis, dengan rumus:

$$
\mathrm{t}=\frac{X 1-X 2}{\sqrt{\frac{s_{1}^{2}}{n_{1}}+\frac{s_{2}^{2}}{n_{2}}}} \text { (Rumus Separated Varians) }
$$

Dengan taraf signifikasi $a=5 \%$. Kemudian dicari tabel pada tabel distribusi $\mathrm{t}$ dengan ketentuan $\mathrm{db}=\mathrm{n}_{1}+\mathrm{n}_{2}-2=12+12-2$ $=22$. Sehingga nilai tabel $=11,646$

a. Membandingkan thitung dan tabel

Berdasarkan hasil perhitungan di atas diperoleh thitung 46,88. Sedangkan tabel $=$ 11,646, sehingga diperoleh thitung $=46,88>$ tabel 11,646. Jadi Ho ditolak.

b. Pengambilan Keputusan

Karena thitung $=46,88>$ tabel $=11,646$, maka ada pengaruh metode pembelajaran Daring terhadap hasil belajar siswa pada mata pelajaran sejarah kelas XI IPA di SMA Shailendra Palembang.

\section{Pembahasan}

Hasil analisis hipotesis menggunakan Independent Sample Test menunjukkan bahwa ada pengaruh metode pembelajaran Daring terhadap hasil belajar siswa pada mata pelajaran sejarah kelas XI IPA di SMA Shailendra Palembang. Karena thitung $=46,88>$ $t_{\text {tabel }}=11,646$, dan dilihat dari kenaikan nilai ratarata yang sebelumnya 71 menjadi 75 , dan dengan perhitungan persentase yakni naik sebanyak 9\%. Maka ada pengaruh metode pembelajaran Daring terhadap hasil belajar siswa pada mata pelajaran sejarah kelas XI IPA di SMA Shailendra Palembang.

Penerapan metode pembelajaran Daring ini sudah pernah diterapkan di SMA Shailendra Palembang. Sampel yang digunakan peneliti pada penelitian ini yaitu purposive sampling atau pengambilan sampel yang dilakukan dengan sengaja dengan mengambil 2 kelas XII sebagai sampel dari penelitian. Jadi sampel pada penelitian ini yakni kelas XII IPA 2 sebagai kelas eksperimen yang berjumlah 24 siswa, dan kelas XI IPA 1 sebagai kelas kontrol yang berjumlah 23 siswa. Variabel X/variabel bebas dalam penelitian ini yakni metode pembelajaran Daring dan variabel $\mathrm{Y} /$ variabel terikat yakni hasil belajar siswa.

Untuk mengetahui pengaruh dari model pembelajaran Daring terhadap hasil belajar pada mata pelajaran sejarah dibuktikan menggunakan t-test, namun sebelum menggunakan rumus ini, data penelitian harus memenuhi uji prasyarat yakni data berdistribusi normal dan data bersifat homogen. Dengan diperoleh $X^{2}$ hitung $\leq X 2_{\text {tabel }}$ atau 46,88 $<135,62$ jadi dapat disimpulkan bahwa hasil tes akhir hasil belajar sejarah dalam penelitian ini berdistribusi Normal. Sedangkan untuk uji homogenitasnya dapat dilihat pada tabel bahwa nilai signifikasi hasil sebesar 0,476 , dengan $\alpha=$ 0,05 . Karena $0,476>0,05$ maka dapat disimpulkan bahwa hasil tes akhir pada mata pelajaran sejarah dalam penelitian ini bersifat homogen.

Kegiatan belajar mengajar dengan menerapkan metode pembelajaran Daring yakni suatu pembelajaran yang dilakukan dengan cara pembelajaran yang memanfaatkan teknologi multimedia, video, kelas virtual, teks online animasi, pesan suara, email, dan video steraming online. Pembelajaran dapat dilakukan secara masif dengan jumlah peserta yang tidak terbatas, bisa dilakukan secara gratis maupun 
berbayar. Hal ini dilakukan untuk menghindari kontak langsung antara pendidik dan peserta didik yang mana sistem pembelajaran secara kovensional atau tatap muka dapat memperluas penyebaran virus Covid-19.

Penelitian ini pernah dilakukan oleh Ulfah Hamidtus Shofiah (2020) dan Tri Darmayanti, Made Yudhi Setiani, Boedi Oetojo (2007) dengan judul penelitian yakni "Penerapan Metode Pembelajaran Daring dalam Mata Pelajaran Bahasa Indonesia di MI Miftahul Huda" dan "E-Learning pada Pendidikan Jarak Jauh: Konsep yang Mengubah Metode Pembelajaran di Perguruan Tinggi di Indonesia". Persamaan penelitian terdahulu dengan penelitian ini adalah sama-sama meneliti mengenai penerapan metode pembelajaran Daring.

\section{SIMPULAN}

Berdasarkan hasil penelitian yang dilakukan, dapat disimpulkan bahwa hasil pengujian hipotesis menunjukkan bahwa adanya pengaruh metode pembelajaran Daring terhadap hasil belajar siswa pada mata pelajaran sejarah kelas XI IPA di SMA Shailendra Palembang. Hal ini dapat dilihat dari: 1. Hasil penelitian terdapat pengaruh metode pembelajaran Daring terhadap hasil belajar siswa pada mata pelajaran sejarah kelas XI IPA di SMA Shailendra Palembang, yakni dibuktikan dengan perhitungan dari t-test yang dimana hasil karena thitung $=46,88>$ $t_{\text {tabel }}=11,646$ maka $\mathrm{Ho}$ ditolak dan $\mathrm{Ha}$ diterima. Dan dilihat dari kenaikan nilai rata-rata yang sebelumnya 71 menjadi 75 , dan dengan perhitungan persentase yakni naik sebanyak $9 \%$.

2. Dari hasil penelitian ini dapat diamati bahwa kelas yang dijadikan kelas uji/eksperimen dengan menerapkan metode pembelajaran ini lebih berpengaruh untuk siswa dalam mengikuti kegiatan pembelajaran yang memanfaatkan internet dan media digital dalam penyampaian materi oleh karena itu siswa dituntut untuk belajar dengan kondusif dan tetap harus fokus dalam menerima pelajaran yang disampaikan oleh guru.

\section{DAFTAR PUSTAKA}

Anugrahana. A. 2020. "Hambatan, Solusi, dan Harapan: Pembelajaran Daring Selama Masa Pandemi Covid-19 Oleh Guru Sekolah Dasar". Dalam Jurnal Pendidikan dan Kebudayaan. Volume 10, Nomor 3.

Ayuni, D, Marini, T, Fauziddin, M, Pahrul, Y. 2020. "Kesiapan Guru TK Menghadapi Pembelajaran Daring Masa Pandemi Covid-19". Dalam Jurnal Obsesi: Jurnal Pendidikan Anak Usia Dini. Volume 5, Nomor 1, 2021. (414-421).

Jayul, A \& Irwanto, E. 2020. "Model Pembelajaran Daring Sebagai Alternatif Proses Kegiatan Belajar Pendidikan Jasmani di Tengah Pandemi Covid-19". Dalam Jurnal Pendidikan Kesehatan Rekreasi. Volume 6, Noomor 2. (190199).

Mustofa, M.I, Chodzirin, M \& Sayekti, L. 2019. "Formulasi Model Perkuliahan Daring Sebagai Upaya Menekan Disparitas Kualitas Perguruan Tinggi". Dalam Walisongo Journal of Information Technology. Volume 1 Nomor 2.

Sugiyono. 2011. Metode Penelitian Pendidikan (Pendekatan Kuantitatif, Kualitatif, dan $R \& D)$. Bandung: Alfabeta.

Sugiyono. 2019. Metode Penelitian Pendidikan (Kuantitatif, Kualitatif, dan R\&D). Bandung: Alfabeta. 


\section{KETENTUAN PENULISAN ARTIKEL JURNAL KALPATARU}

1. Naskah berbahasa Indonesia yang disempurnakan bertemakan kesejarah yang meliputi hasil penelitian sejarah, pengajaran sejarah dan penelitian kebudayaan.

2. Naskah harus asli dan belum pernah dimuat dalam media lain. Naskah dapat berupa hasil penelitian/artikel kajian konseptual yang ditulis oleh perorangan dan atau kelompok.

3. Naskah ditulis dengan cara-cara yang sesuai dengan ketentuan penulisan artikel ilmiah menggunakan bahasa Indonesia yang baku, berupa ketikan, beserta soft file dalam CD-RW atau dengan mengirimkan email pada redaksi jurnal Kalpataru dengan alamat jurnalkalpatarusejarah@gmail.com, spasi tunggal, jenis huruf arial narrow ukuran 12, dengan panjang naskah antara 8-15 halaman pada kertas A4.

4. Artikel hasil penelitian memuat:

JUDUL

Nama Penulis

Abstrak

A. PENDAHULUAN

B. METODE PENELITIAN

C. HASIL DAN PEMBAHASAN

D. SIMPULAN

DAFTAR PUSTAKA
: XXX (HURUF KAPITAL)

: (disertai jabatan, institusi, dan email)

: (Bahasa Indonesia yang memuat 100-200 kata diikuti kata kunci, dengan jenis huruf arrial narrow dan ukuran huruf 11 serta dicetak miring).

: (memuat latar belakang masalah, tinjauan pustaka secara ringkas, masalah penelitian, dan tujuan penelitian).

5. Artikel Kajian Konseptual memuat:

JUDUL

Nama Penulis

Abstrak

PENDAHULUAN

Sub Judul

Simpulan

DAFTAR PUSTAKA
: (berisi simpulan).

: (berisi pustaka yang dirujuk dalam uraian naskah).

6. Referensi sumber dalam teks artikel ditulis dengan menggunakan side note, contoh (Jalaludin, 1991:79); sementara penulisan daftar pustaka disusun dengan ketentuan. Nama pengarang. Tahun terbit. Judul (dicetak miring). Kota terbit: Nama Penerbit. Contoh: Koentjaraningrat. 2010. Manusia dan Kebudayaan di Indonesia. Jakarta: Djambatan. Daftar pustaka hanya memuat pustaka/sumber yang dirujuk dalam uraian dan disusun menurut abjad tanpa nomor urut.

7. Naskah yang dimuat akan disunting kembali oleh redaksi tanpa mengubah isinya.

8. Naskah yang ditolak (tidak bisa dimuat) akan dikirim kembali ke penulis dengan pemberitahuan tertulis dari redaksi atau melalui email.

9. Penulis yang naskahnya dimuat akan mendapat 1 (satu) majalah nomor yang bersangkutan.

10. Kontak person: Muhamad Idris (081271498618); Eva Dina Chairunisa (082281267851); Jeki Sepriady (085269261780). 